\title{
АКАДЕМИК ӘЛКЕЙ ХАҚАНҰЛЫ МАРҒҰЛАН МҰРАСЫ
}

\author{
(C) 2018 ж. Ә.М. Манапова
}

Әлкей Хақанұлы Марғұланның есімі әлемдік ғылымда кең танылған. Ә.Х. Марғұланның бізге қалдырған мұрасы - бұл әлемдік мәдениет қазынасына қосылған теңдесі жоқ мұра. Ә.Х. Марғұлан алғаш рет Сарыарқаны өз бағытымен қамтыған ҚазКСР ҒА Орталық Қазақстан археологиялық экспедициясының ұйымдастырушы және жетекшісі болды. «Ежелгі Қазақстан қалалары мен құрылыс өнерінің тарихынан», «Орталық Қазақстандағы Беғазы Дәндібай мәдениеті» монографияларының баспадан шығуы еліміздің ғылыми өміріндегі аса ірі жаңалық болды. Зерттеушінің Қазақстан археологиясы, архитектурасы, этнографиясы, ежелгі және ортағасырлық тарихы, әдебиет және өнер тарихының басты мәселелеріне арналған 300-ден астам ғылыми және ғылыми танымдық мақалалары жарық көрді. Академик Әлкей Хақанұлы Марғұлан - жан-жақты ғалым. Зерттеген әр салаға өзінің мол мұрасын қосты. Археологиялық мәдени мұраны зерттеуі ең маңыздысы.

Түйін сөздер: археология, Ә.Х. Марғұлан, Орталық Қазақстан, мұра, сәулет, этнография, тас дәуірі, қола дәуірі, металургия, ортағасыр, қалалар

Таудың биіктігі алыстаған сайын байқалатыны сияқты уақыт өте келе Әлекей Хақанұлының өмір жолы, ғылымда алған орны ұлғая түсуде. Қазақтың белгілі энциклопедист ғалымы, Қазақ КСР Ғылым Академиясының академигі, Қазақстан ғылымына еңбегі сіңген ғылым қайраткері, филология ғылымының және мәдениеттану ғылымының докторы, профессор Әлкей Хақанұлы Марғұлан (1904-1985) алпыс жылдан аса өмірін қазақ халқының тарихын зерттеп, дамытуға археология, этнография, сәулет өнері, өнертану, әдебиет және қазақтың халық ауыз әдебиетінің келелі мәселелерімен айналысты.

Қоғамдық ғылымдардың әртүрлі салаларына қомақты үлес қосқан ғұлама ғалым, өзі зерттеген әр саланы ұлттық ғылыми дәрежесіне жеткізді, фольклористика, археология, этнография, көне сәулет тарихы т.б. салада қомақты еңбектер қалдырды. Ленинградта іргелі білім алған академик ғалым өзінің бүкіл саналы өмірін ғылымға арнады. Қазақ жерінде сақталған көне ескерткіштер туралы жазылған деректерді терең зерттеп, олардағы мәліметтердің тым аз екенін, елдің, жердің тарихын толықтыратын тек археология екеніне көзі жетті. Ә.Х. Марғұлан археология ғылымының барлық дерлік мәселелеріне тоқталып өтіп, жәнеде өзінен кейінгі зерттеушілерге археология ғылымының дамуы үшін теориялық бағыт бағдар берді. Бұған дейін археолог күрегі тимеген Сарыарқамен мыңдаған шақырым аймақта зерттеу жүргізген ғалым 
Манапова Ә.М. Әлкей Хақанұлы Марғұлан мұрасы

Орталық Қазақстанда қалыптасып өмір сүрген әртүрлі тарихи кезеңдерден сақталған өркениет ошақтарын ашып, ғылыми айналымға енгізді.

40-жылдардың басынан бастап көне жазба ескерткіштері және қазақ халқының рухани мәдениетін, фольклорын жан-жақты зерттеумен бірге Қазақстан жеріндегі археологиялық ескерткіштер комплексін іздестіру, табу және зерттеу ісін алғашқылардың бірі болып бастады [Библиография ученых Казахстана, 1984].

Археология дегеніміз - бұл өткен заман ескерткіштерін үздіксіз іздеу, заттай мәдениет комплекстерін, ерте замандағы адамдардың іздерін ашу. Өзімнің экспедициямды, адамдармен сұхбатымды, қазба жұмыстарымды, тапқан заттарымды еске алсам - бұл менің өмірімдегі өте бақытты да қуанышты күндерім. Далада еңбектің бағасы, іске және сөзге деген адалдық сыналады. Мұндай өнбейтін жұмысқа шыдам керек дей келе, мен археолог ғалым М.П. Грязнов пен С.И. Руденконың экспедициясына қатыстым, А.Н. Бернштам, С.С. Черников, Л.Р. Кызласов және басқа да еліміздің атақты ғалымдарымен бірге жұмыс істедім. Өзімнің оқушыларым К.А. Ақышев, М.К. Қадырбаев, Х.А. Алпысбаев, А.М. Оразбаевпен жәнеде жас коллегаларым C.M. Ақынжанов, К.М. Байпақов, Л.Б. Ерзаковичпен және басқаларымен де жұмыс істедім - дейді Н.Э. Масановпен сұхбатында.

Ол археологиялық зерттеу жүргізіп, ол жүргізген зерттеулерін қортындыламас бұрын өзіне дейінгі жүргізілген зерттеулерге тоқталып, сараптама жасап отырған. Мысалы ол «Шығыс Бетпақ - даланың тарихи топографиялық фоны», - деген мақаласында Шу және Сарысу өзендерінің бассейндеріндегі ескерткіштер жөніндегі мәліметтер: академик А.И. Шренк, Ш. Уәлиханов, геодезист Ю.А. Шмид, статист Л.Р. Чермак, тау инженері А.А. Козырев, гидротехник А.П. Соловьев және басқалардың жазбаларында көрсетілген деп жазды [Маргулан,1950]. Бұдан ғалымның қаншама салалар бойынша мәліметтермен қанық екенін байқауға болады.

Оның негізгі жеткен жетістігі Қазақстанды кейбір зерттеушілер айтқандай тіршіліксіз дала, уақыт өте кейбір көшпенділердің жолы ғана түйісетін аймақ деген тұжырымын жоққа шығаруы болды. Қазақстан жерінде тіршіліктің, көне мәдениеттің болғандығын, бірақ әртүрлі жағдайларға байланысты олар үзіліп, көне қоныстарды құм басқанын ғылыми тұрғыда анықтап, өз зерттеулерімен дәлелдеп берді.

Қазақстанда бір-бірімен тығыз байланысты әр түрлі мәдени шаруашылық типтердің болғандығын да Ә.Х. Марғұлан бірінші рет күн тәртібіне қойып оны жан-жақты зерттеудің қажеттігін әрқашан айтып отырды. Ол кезде Қазақстанның археологиялық зерттеу тұрғысында ғылым үшін берері болымсыз деушілер пікірі басым болғандықтан да, оның бұл саладағы ғылыми зерттеулерінің маңызы аса зор болды. Осындай келелелі мәселелермен айналысқан ғалымды Қазақстандағы археология ғылымының негізін салушылардың бірі деуіміз әбден орынды.

Оның археологияға қызығушылығын 1948 ж. Мәскеу Университетінің археология кафедрасының студент-дипломнигі кезінен таныс болған Л.Р. Кызласов - Ә.Х. Марғұлан жайында жазған 
өзінің мақаласында Әлкей Хақанұлы Марғұланды үш қырынан көрсетеді: бірінші және негізгісі туған жеріне және өз халқына берілгендігі, екіншіден ғылымға берілгендігі, үшіншіден даладағы барлау жұмысына батыл кірісіп кететіндігі. Жаратылысынан аттан түспеген ол түйе үстінде сағаттап желе беретін, «тума талантты шабандоз еді», - деп есіне алады. Сонымен қатар: «Речь пойдет не только об ученом человеке Маргулане, но и об его стране Центральном Казахстане. Удаленные почти на полстолетия, туда, назад, в конец 40-х годов, оба они Маргулан и Центральный Казахстан - оказались для меня неразрывно связанными и одинаково памятными. Тогда, в 1948 году, наступал третий сезон моего путешествия в Древнетюркский каганат, в его увлекательнейшую историю, в его чудом сохранившийся быт... В 1946 и 1947 гг. я работал в Туве» [Кызласов, 2004], - деп Орталық Қазақстан мен Ә. Марғұланды бөліп қарай алмайтынын жазды.

Соғыстан кейінгі жылдарда Ә.Х. Марғұланның негізгі ғылыми зерттеу жұмысы көне мәдени ескерткіштерге өте бай, бірақ шын мәнісінде әлі зерттелмей ғылым үшін беймәлім болып келген Орталық Қазақстанмен тікелей байланысты болды.

\section{6 жылы тікелей}

Ә.Х. Марғұланның ұйымдастыруымен Орталық Қазақстан археологиялық экспедициясы құрылды. Аты Орталық Қазақстан археологиялық экспедициясы болғанымен экспедиция Қазақстанның басқа аймақтарында да зерттеу жұмыстарын жүргізді. Олар Оңтүстік, Батыс Қазақстан өңірлері. Ә.Х. Марғұланның алғашқы жылғы есебінен оның ежелгі тарихты өте жақсы білгендігін байқауға болады. Әр ескерткішке жан жақты сипаттама беріп, өзіне дейінгі зерттеушілер еңбектеріне сілтеме жасап салыстырмалы түрде өз ойын жеткізіп отырады. Есепке жалпы шолу жасасақ: тас балбалдар, тастағы таңбалар, архитектуралық құрылыстар, ежелгі елді мекендер жөнінде мәлімет аламыз. Қаратаудың солтүстік жазығынан (ежелгі Созақ, Баба Ата, Құмкент, Шолақ Қорған, Саудакент, Күлтөбе, Ақтөбе және т.б.) ежелгі қала қалдықтары зерттелді деген жолдардан ортағасырлық қалалар мәселесі алғашқы жылдан-ақ ғалымның назарынан тыс қалмағанын көреміз [Маргулан, 1948].

Ә.Х. Марғұлан өз зерттеулерінде кең ауқымды аймақтарды ғана емес, хронологиялық шеңбері мол ескерткіштерді қамтыды. Ол өз зерттеулерінде неолит дәуірінің тұрағын, Беғазы-Дәндібай және андрон мәдениетінің қоныстары мен қорымдарын, ерте көшпенділер археологиялық ескерткіштері мен халықтардың Ұлы қоныс аударуы тұсындағы ескерткіштерді, тас мүсіндер мен тасқа салынған суреттерді, ирригациялық құрылыс пен ежелгі керуен жолдарын, VIII-X ғасырлардағы тастан жасалған архитектураның ескерткіштері және ортағасыр қалаларын, XIII-XIV ғғ. мавзолейлер мен XIV-XIX ғғ. қазақ күмбездерін ашты. Әр жылдардағы жұмыс қорытындылары Ғылым Академиясының хабарларында үзбей жарияланып отырды.

Әлкей Хақанұлының көп жылғы еңбегі К. Ақышев, Ә. Оразбаев, М. Қадырбаевтармен бірігіп жазған «Орталық Қазақстанның ежелгі мәдениеті» [Маргулан и др., 1966] атты кітапта қорытындыланды. 
1967 ж. осы ұжымдық монография Қазақ КСР ҒА-ның Ш.Ш. Уәлиханов атындағы мемлекеттік сыйлықты иеленді.

Осыдан кейінгі келелі іргелі зерттеу еңбегі көп жылдық зерттеу жұмыстарыныңжемістіқорытындысы «Орталық Қазақстандағы Беғазы Дәндібай мәдениеті» монографиясы 1979 ж. шықты, бұл кітабы археологиялық ғылыми әдебиеттің алтын қорына енді. Кейін бұл еңбек 1998 ж. ғалымның шығармалар жинағының бірінше томына енді.

Ә.Х. Марғұланның ежелгі заман ескерткіштерінің ішінде тас дәуірі ескерткіштерін зерттеуі кешенді болмағанмен Қазақстанда жүргізілген зерттеулерді саралаған еңбектері мол. Оның 1998 ж. жарық көрген шығармалар жинағының 1 томында тас ғасыры ескерткіштерінің зерттелуіне жан жақты тоқталып, сараптама жасалды. Осы еңбегінде соңғы 40 жыл ішінде Қазақстанда неолит ескерткіштерін ашу мен зерттеуде археологтар көп жұмыс атқарғандығын талдап жазды.

Ә. Марғұланның зерттеулерінің негізгі бағыты қола дәуірі болды. Қола дәуірі ескерткіштері басқа тарихи кезеңдерге қарағанда көбірек зерттелгенімен, көптеген мәселелер әлі де түбегейлі шешіле қойған жоқ. Мұның өзі отандық археология ғылымының үздіксіз дамуын көрсетеді [Құрманқұлов, 2008].

Қазіргі күнде Ә. Марғұланның ғылыми еңбектерінің арқасында сақтар мәдениеті андронов мәдениетінің заңды жалғасы екендігі толық дәлелденсе, бұл екі мәдениеттің арасында БеғазыДәндібай мәдениетінің дәнекерлік роль атқаратындығы ғылыми тұрғыда негізделді. Беғазы-Дәндібай мәдениеті әлеуметтікэкономикалық даму деңгейі және мәдени жетістігінің көрнектілігі жағынан Триполье, Қарасуктан кем қалмайтын Сарыарқадағы тамаша құбылыс. Бұл мәдениетке ғалым Беғазы, Бұғылы, Саңғыру, Айбасдарасы, Дәндібай ескерткіштерін жатқызады. Қола дәуірінің немесе Беғазы-Дәндібай мәдениетінің ескерткіштері шығысы Абыралы тауы мен Шыңғыс жотасынан батысы Ұлытау тауына дейін созылып жатыр. Орталық Қазақстанның қола дәуірін айғақтайтын этап ескерткіштері өзіндік ерекшеліктерімен бөлініп көрінеді, бұл бізге дейін жеткен алғашқы монументалды құрылыс (XII-X және X-VIII ғғ. б.д.Д.) деп көрсетті Ә.Х. Марғұлан [Маргулан, 1979].

Ғұлама ғалым қазақ даласында металлургияның даму тарихына көп көңіл бөліп, ежелгі металлургияның көптеген ескерткіштерін ашты және сипаттамасын берді. Олар: Жезқазған, Саяқ, Алабұға, Үрпек, Имантау, Шақпақ, Суық Бұлақ, Атасу. Ол өзінің еңбектерінде қазақ даласы алтын мен мыс елі екендігі туралы ертедегі Геродот, Әл-Идриси, Әбілғазы т.б. еңбектерінде кездестіреміз деп атап көрсетеді.

Орталық Қазақстанның топонимикасында кенге байланысты терминдер көптеп кездеседі: Жезді өзені, Жезқазған, Қазан сынған кен қорыту кезінде қазан сынған жер, Қалайы қазған, Кенгей, Кенгір өзені, Кен қорытқан, Қорғасынтау, Ұстаның жалы, Темірші тау. Қазіргі уақытта ғалымның сипттамаларының дәлелі іспетті Орталық Қазақстан археологиялық экспедициясы Жезқазғаннан алпыс шақырымдай жерде Талдысайда металлургия орталығын ашып зерттеуде.

Қола дәуірінен беріқарай келе жатқан тағы бір ескерткіштер тобы, су қоймалары - тоғандар, Ә.Х. Марғұлан 
еңбектерінде ерекше орын алған көктемгі суы тез сарқылатын далада егін салуға мүмкіндік беретін бұл құрылыстардың маңызы зор. Қарапайым адам мүлдем көңіл аудармайтын жер бетінде нобай ғана сақталған бұл тоғандарды тауып, зерттеп, жобасын сызып алу тек Ә.Х. Марғұлан сияқты қазақ даласын алақанындай оқи білетін, аңғарымпаз кісінің ғана қолынан келеді. Ол кісі оннан аса тоғандардың сипаттамасын беріп, сызбасын жасады.

Ә.Х. Марғұланды «мұртты қорғандарды» зерттеушілердің алғашқыларының бірі деуімізге оның басшылығымен 1946 ж. археологиялық экспедицияның есебі ретінде жазған мақаласы дәлел бола алады. Экспедиция Қарағанды облысының Ұлытау, Жезқазған, Жаңаарқа аудандары территориясында орналасқан қорғандарды зерттеді. Қорғандар Сарысу, Кеңгір, Жезді, Байқоңыр және Бұланты өзендерінің маңында көптеп кездеседі.

Сарыарқадағы сақтардың

өнер туындылары, дүниетанымын көрсететін тасбетіндегі суреттердің ipi тобын Ә.Х. Марғұлан Байқоңыр, Бұланты бойынан, Теректі әулие бұлағының басындағы таулардан тауып зерттеген. Автордың анықтауынша олардың дүниетанымының биік дәрежеде болғаны, өнерінің жетік екені дәлелденген.

Қазақстанның ортағасырлық археология тарихы өте тереңде жатыр. Ортағасырлық ескерткіштерге археологиялық зерттеулер жүргізу арқылы сол уақыттағы халықтардың тыныс-тіршілігінен, сол уақыттың мәдени және саяси өмірінен мол мағұлматтар аламыз. Отандық ғылымда Ә. Марғұланның ортағасырлық ескерткіштерді зерттеулерде алар орны ерекше. Оның жан-жақты

ғылыми-зерттеу еңбектерінде ортағасырлық Қазақстандағы қыпшақтардың этномәдени құрылысы мәселесі жоғары орын алады. Болашақта қазақ халқының этноқұрылымында қыпшақ мәселесі негізгі кілті болатыны сенімді болған Ә.Х. Марғұлан бұл мәселені жан-жақты қарастырып отырды. Шығыстанудың ленинградтық классикалық мектебінен алған білім оның мұсылман әлемінің жазбаша ескерткіштерін араб, парсы, ежелгі түрік жазбаларын түпнұсқадан оқуына мүмкіндік жасады. Ол ортағасырлық Ибн Хордадбех, Ибн ал-Факих, Гардизи, ал-Идриси, Бируни, Махмуд Кашгари, Закрия Казвини, Жамал Кашри, Ауфи және басқа да көптеген авторлардың еңбектерін ғылыми айналымға қосты.

Әлкей Хақанұлы Марғұлан жас ғалымдар мен аспиранттарына тарихи деректерді рет-ретімен қарауға, қол жетерлік барлық жазба ескерткіштерді қамтуға, әр уақыттағы, әртүрлі бағыттағы және кей уақытта бір-біріне қарама қайшы келетін пікірлерді анықтауға әрқашанда жол сілтеп отырды. Ә.Х. Марғұлан қыпшақтануда айқын із қалдырды, - деп баға берді ҚР ҰҒА академигі Б.Е. Көмеков [Кумеков, 2004].

Ә.Х. Марғұлан XIV ғ. бірінші жартысы деп танылған Нұрадағы қыпшақ қабірін ашты. Бұл қыпшақ қабірі жөнінде 1959 ж. жан-жақты зерттеп, [Маргулан, 1959] келелі мақала жариялады. Ал академиктің басты мақсаты болған ежелгі түркі тақырыбын оның үш оқушысы жалғастырды. C.M. Ақынжанов қыпшақтар жөнінде бағалы еңбек қалдырды, Б.Е. Көмеков араб және парсы деректері бойынша қимақтар мәселесін, А.Ш. Қадырбаев XIIIXIV ғғ. түріктер мен ирандықтар жайында ортағасырлық қытай деректерін сөйлетті. 
Ә. Марғұлан қазақ жеріндегі тас мүсіндерді де ғылыми тұрғыда түбегейлі зерттеді. Ол тас мүсіндерді тауып, көзімен көріп, қолымен ұстап, бұл жөнінде салиқалы ой айтып, ғылыми тұжырым жасады. Сөйтіп, бұл ескерткіштердің қазақ халқының көне замандарда осы өңірді мекендеген ата-бабаларының мұрасы екендігін ғылыми тұрғыдан дәлелдеп берді. Сыртқы құрылысы бойынша тас мүсіндер екі түрде кездеседі; бір тобы граниттен жасалған төрт бұрышты тас шарбақтың күншығыс жиегінде, екінші тобы үйген тас обалардың күншығыс жақ етегінде. Ғұлама ғалым ежелгі мал өсіруші тайпалардан қалған жоғарыдағы тас мүсіндерді егжей-тегжейлі зерттей келе, олардың даму тарихын екі кезеңге бөледі. Ә. Хақанұлының айтуынша, мұның бірі VII-VIII ғғ. Түркі қағанаты дәуірінде орнатылған тас мүсіндер, екіншісі VII-XIII ғғ. Орталық Қазақстанды мекендеген Қыпшақ тайпаларынан қалған ескерткіштер.

Академик Ә. Марғұлан Қазақстанның ортағасырлық қалаларын зерттеудің негізін қалаушылардың бірі болды. Археолог-ғалым басқарған Орталық Қазақстан археологиялық экспедициясы (ОКАЭ) 1946-1950 жж. Орталық Қазақстанда, Оңтүстік Қазақстанда, Талас, Шу өңірлерінде және Батыс Қазақстанда археологиялық зерттеу жұмыстарын жүргізді.

Орталық Қазақстанда жүргізген археологиялық зерттеулердің барысында 60-тан аса ортағасырлық қалалар мен бекіністер т.б. ескерткіштер ашылды. Олардың 10ға жуығы Есіл өзенінің бассейнінде, 9-ы Нұраның бассейнінде, 10-ы Сарысудың жағасында, 10-ы Кеңгір өңірінде, 4-і Жезді өзенінің жағасында, 10-ы Ұлытаудың оңтүстік беткейінде, 1-і Ақтауда, 1-і Мойынты өзенінің жоғарғы ағысында, 3-і Қарқаралы тауында, 2-і Баянауыл ауданында орналасқан [Маргулан, 1978].

Ортағасырлық керуен жолдарын зерттеуде Ә. Марғұланның еңбегі көңіл аударарлық. Оның бір зерттегені Бетпақдала бойымен өтетін бірнеше керуен жолдары. Бетпақдала - Қазақстанның оңтүстігі мен орталық Қазақстан арасында жатқан байтақ шөл дала. Мұның ішінде белгілілері «Хан жолы», «Қарқаралы жолы», «Уанас жолы», «Жетіқоңыр жолы», «Сарысу жолы». Бұлардың барлығы бұрын оңтүстік өлкелермен Орталық Қазақстанды, Ертіс бойын, Күнбатыс Сібірді байланыстырып, олардың арасында мәдени, сауда қарымқатынастарын күшейтуде маңызды болған жолдар [Маргулан, 1949].

Ғалым Тараздан шыққан керуен жолы Оққұм, Қызылқорғанды басып өтіп, Болаттауға барғанда Қарқаралы мен Хан жолдарына қосылған дейді. Бұл пікірді Б.Е. Көмеков те қолдайды. Ал М. Елеуов қолдай отырып, қимақ жолының бағытын былайша көрсетеді: Тараздан солтүстікке бет алған қимақ жолы Қоңыртөбе, Шөлтөбе, Кавакеттегі елді мекендер арқылы Қонысбай, Оққұм, Төрткүл, Ынтымақ, Шаруашылық, Байжантөбе қалары мен елді мекендерінен өтіп, Ұланбел өткеліне барғанда, Шу керуен жолын кесіп өтіп Шудың оң жағасына шыққан, онан әрі Қызылтұз шатқалы, Ұзынтау, Ақбастау, Саркөл шатқалдары арқылы өтіп Болаттауға барғанда, Хан жолы мен Қарақаралы жолына қосылған [Елеуов, 1999].

Академик Ә. Марғұлан Уанас, Жетіқоңыр жолдары туралы былай дейді: «Уанас және Жетіқоңыр жолдары оңтүстіктегі Отырар, Түркістан және Созақ қалаларынан басталған. Созақтан бірге шыққан бұл жол Шу өзеніндегі Тайөткел (не 
Көкмұрынтай) өткеліне жеткенде екіге бөлінген: бір жол Жетіқоңыр құмдарына қарай бет алса, ал екінші жол (Уанас) Сарысу, Есіл, Нұра өзендері алқабына Ертістің Төменгі ағысына дейін жалғаса берген» [Маргулан 1949].

Оның 1950 ж. шыққан «Ежелгі Қазақстан қалалары мен құрылыс өнерінің тарихынан» деген еңбегі ортағасырлық Қазақстанның, нақтылай түссек Жетісудан Оралға дейінгі қалалар жөніндегі бірінші еңбек болды. Осы келелі еңбегінде ғалым: «археологиялық материалдар VI-VIII ғғ. Орта Азия мен Қазақстанда қалыптасқан қоныстарды типтерге бөлуге негіз болды. Қоғамдық және тұрғын үйлердің қираған құрылыстарына қарап қоныстарды 6 түрге бөлді. Олар: сауда және қолөнер қоныстары, әскери қамал, керуен сарайлар, жер шаруашылық қоныстары болды. Мұндай қоныс түрлері бір-біріне құрылыс техникасы жағынан ұқсас болғанымен, салу жоспарлары және өлшемдерінде айырмашылықтар болды»,-деп қорытты [Маргулан, 1950а]. Сонымен қатар, осы еңбекте Қазақстандағы құрылыс өнерінің даму тарихы да сараланған [Маргулан, 1950a].

Ә.Х. Марғұлан алғашқы болып, отырықшылық мәдениеттің және қалалық мәдениеттің бұрын ғылымда айтылмағын куәларын тауып жаңалық ашты. Ә.Х. Марғұланның этнография саласындағы еңбектеріне келетін болсақ оның әр жылдары жарияланған этнографиялық мақалаларымен қоса қазақтың қолөнері жөніндегі еңбектері ерекше. Бірнеше жыл этнография бөлімін басқара отырып Ә.Х. Марғұлан этнография ғылымының дамуын көп ықпал етті.

Академик Ә.Х. Марғұланның көпқырлығылыми-зерттеуқызметінде ортағасырлық Қазақстандағы қып- шақ этномәдени қауымының өзекті мәселелері маңызды орын алды. Ә.Х. Марғұлан қазақ фольклорын, оның ішінде қазақтың тарихи жыраңыздарына сүйеніп тарих пен этнографияны өзара бір-бірімен тығыз байланыстырып, кешенді тұрғыдан зерттеді. Ол көптеген этнографиялық экспедициялар нәтижесінде қазақ халқының рухани мәдениетіне жататына баяғы заманнан бері келе жатқан көптеген тарихи жыр, аңыздарды, хикаяларды жинап, тарихи тұрғыдан ғылыми құндылығын талдады.

Қазақстанның өнері мен мәдениет тарихының мәселелеріне де Әлкей Хақанұлы ерекше назар аударды. «Қазақтың халықтық қолөнері» атты іргелі еңбегі - этнографиялық және өнертану саласындағы ғылыми ізденістердің тоғысқан тұсы, көп жылдық экспедициялық сапарлардың нәтижесі. Онда қазақтың тұрмыстық заттары жүйелі түрде зерттеліп, олардың жасалуы мен жетілдірілуі көрсетіледі. Шын мәнінде, бұл қазақ қолөнерінің энциклопедиясы, халықтық көркем шығармашылықтың аса көрнекті туындысы. Туған жерге, туған елге деген махаббат оның бүкіл өмір бойына нәр алған таусылмас қайнар бұлағы болды.

Ә. Хақанұлы қазақ халқының этнографиясына байланысты еңбектерінің бірі 1985 жылы жарық көрген ipi монографиялық еңбегі «Ежелгі жыр аңыздары» [Марғұлан, 1985]. Бұл еңбекте ол алғаш рет халықтың жыраңыздарын тарихи дерек есебінде пайдаланды.

Ә.Х. Марғұлан археологиямен этнографияны және ауыз әдебиетімен ұштастыра отырып зерттеулер жүргізді. Оның тағы да көңіл бөліп, Қазақстан ғылымы үшін керек екенін түсінген саласы антропология 
ғылымы. Қазақстандағы антропологиялық зерттеулердің негізгі шешімдері жеке ғылыми баяндама ретінде Халықаралық конгресстер мен конференцияларда және симпозиумдарда баяндалды. Мысалы 1964 ж. Москва қаласында, 1968 ж. Токио және Киото қаласында өткен Халықаралық конгреске академик Ә.Х. Марғұлан да қатысты. Осындай естеліктерге қарап ғұлама ғалымның Қазақстан ғылымында тағы да бір саланың дамып, өркендеуіне үлкен үлес қосқанын көреміз.

Жас кезінен - ақ ғылым жолын таңдаған Әлкей Хақанұлы оған өте беріліпкеткендігісонша,тіптідемалыс уақытында да өзінің зерттеулерімен айналысты. Ол кешкісін уақытында қолына домбыра алып күй ойнайтын, өзінің сүйікті әнін салатын. Осы уақытта көз алдыңа шексіз сары дала мен ежелгі қалалар өтіп жатқандай болатын еді. Әлкей Хақанұлының қолжазбасын оқығанда көзге түсетіні даланың бейнесі елестейді. Ол өзінің көшпенділер тіршілігіне таңқалысын жасырмайтын. Туған жерге, өз халқына деген ыстық сезімі, әдемілікке құштарлығы жоғары еді [Маргулан Д.А., 1996], - деп еске алады ғалымның қызы Дәнел Әлкейқызы.

Әлкей Хақанұлының қазақ халқының мәдениеті мен тұрмысын, әдет-ғұрпын, салт-санасын жанжақты терең білгірлігі, көшпенділік өмірдің қыр-сырына қанықтығы оның эпикалық жанрдағы зерттеулерінің жан-жақтылығы мен ғылыми тереңдігінің басты кепілі болды. Ә. Марғұлан тарих, археология, этнография, әдебиет және өнер тарихынан 300-ден астам ғылыми зерттеу жұмысының, 100 ден астам энциклопедиялық мақалалардың авторы. Ә.Х. Марғұланның жұмыс стиліне тән ерекшеліктердің бірі - оның бірнеше проблеманы зерттеу ісін қатар жүргізуінде. Ол проблемалардың әрқайсысын орындау үшін ондаған ғалымдар көп жылдарын жұмсаған болар еді. Ә.Х. Марғұлан Академияда және Тарих институтында ол он жылдан аса Ш.Ш. Уәлиханов (1961-1972) жайлы материалдарды жүйелеумен айналысты, КСРО мұражайы материалдарын қопарып, Ш. Уәлиханов қаламынан шыққан 300-ге жуық еңбектер тапты. Ол сол еңбектерді өңдеп, жүйелеп, қателерін түзетіп басып шығарған. Нәтижесінде Ш. Уәлихановтың 150 жылдығына арналған 1958 жылы Ш. Уәлихановтың таңдамалы шығармалар жинағы басылып шықты.

Ә.Х. Марғұлан үлкен ғылыми, педагогикалық еңбекті ұйымдастыру ісімен де ұштастыра біледі. Ол көп жылдар бойы этнография бөлімін басқарды, қазақ халқының шығу тегі туралы үйлестіру кеңесін басқарды, онымен бірге Қазақ КСР тарихының барлық басылымдарында редколегия мүшесі болды, Қазақ КСР ҒА Тарих, археология және этнография институтының ғылыми советінің, маманданған докторлық және кандидаттық диссертациялар қорғау советінің мүшесі болды.

Ә.Х. Марғұлан - дүние жүзі ғалымдарының сан алуан жиындарында, конгрестер мен симпозиумдарда ғылыми баяндамалар жасады. Әсіресе шығыстанушылардың XXV конгресінде «Орталық Қазақстанның қола дәуірі мәдениетінің жаңа ескерткіштерінің ашылуы» [Маргулан, 1960], VIIVIII антропология және этнография ғылымының дүниежүзілік конгресінде жасаған «Қазақ киіз үйі», «Қазақстанның исламға дейінгі архитектурасы» атты баяндамалары ғылымға қосан үлкен үлес ретінде 
жоғары бағаланып, ғалымдар назарын бірден аударды. Ә. Хақанұлы шетелдік шығыстанушы, археолог және этнограф ғалымдармен тығыз байланыс жүргізді. Оның ғылыми еңбектерінің бірқатары шет тілдеріне де аударылды.

Ә.Х. Марғұлан отанымыздағы көптеген ғылыми мекемелермен тығыз байланыс жасауға көп көңіл бөлді. Оны Москва, Ленинград, Новосибирск, Ташкент, Фрунзе және Душанбе қалаларына сан рет диссертациялық жұмыстарға оппоненттікке шақырған.

1946 жылы КСРО Ғылым академиясының Қазақ филиалы Қазақ КСР Ғылым академиясына айналды да, республиканың көрнекті ғұлама ғалымы Ә.Х. Марғұлан академияның корреспондент-мүшесі, ал 1958 жылы толық мүшесі болып сайланды. 1960 жылы оған профессор атағы берілді [Библиография ученых Казахстана, 1984].

Әр жылдары еңбегіне қарай марапатталды: 1942 ж. Қазақ КСР Жоғары Советі грамотасымен; 1944 ж. Қазақ КСР Жоғары Кеңесі грамотасымен; 1945 ж. «19411945 жж. Ұлы Отан соғысындағы ерлік еңбегі үшін» медалімен; 1955 ж. Қазақстан ЛКЖО Орталық Комитетінің Құрмет грамотасымен; 1964 ж. Қазақ КСР Жоғарғы Кеңесі Құрмет грамотасымен; 1967 ж. «Орталық Қазақстанның көне мәдениеті» атты монографиясы үшін
Ш.Ш. Уәлиханов атындағы Қазақ КСР ҒА-ның сыйлығына ие болды.

Осы жылы Ленин орденімен; 1970 ж. «Ерлік еңбегі үшін. В.И. Лениннің туғанына 100 жыл толуы құрметіне» медалімен; 1973 ж. Қазақ КСР Жоғарғы Кеңесінің Құрмет Грамотасымен; 1974 ж. Еңбек Қызыл Ту орденімен марапатталды. Ал 1982 ж. Қазақ КСР Мемлекеттік сыйлығының лауреаты атанды. 1984 ж. Халықтар достығы орденімен марапатталды.

1991 ж. 28 тамызда ҚазКСР Министрлер кабинетінің № 496 “Ә.Х. Марғұлан атындағы Археология институтын құру" жөнінде қаулысы шықты. 1991 ж. 6 қыркүйекте Археология институты жөнінде ҚазКСР ҒА Президиумының қаулысы қабылданды. Қаулы бойынша жаңа құрылған Археология институтына Қазақстан археологиясының негізін қалаушылардың бірі белгілі ғалымы археолог, тарихшы, филолог, этнограф - республикалық ғылым академиясының академигі Әлкей Хақанұлы Марғұланның есімі берілді. Қазақстан Республикасы Үкіметтің 2004 жылғы 4 ақпандағы № 136 қаулысымен бекітілген Академик Ә.Х. Марғұланның 100 жылдық мерейтойын өткізу жөніндегі ісшаралар жоспары бойынша 2004 жылы орнатылуға тиіс ескерткіш 2008 ж. қаңтар айында Ұлттық Ғылым академиясының бас ғимаратының жанына орнатылды.

\section{ӘДЕБИЕТ}

1. Байпақов К.М., Ақышев К.А. Қазақ археологиясының атасы // Қазақ тарихы. 1994. № 2. 7-10-бб. 1984. $67 \mathrm{c}$

2. Библиография Ученых Казахстана. А.Х. Маргулан. Алма-Ата: Наука,

3. Елеуов М.Е. Шу Талас өңірлерінің ортағасырлық қалалары мен мекендері (VI-XIII ғ. басы): тарих ғыл. докт. ... автореф. Алматы, 1999. 19 б.

4. Кумеков Б.Е. А.Х. Маргулан как кипчаковед//История цивилизации и духовной культуры кочевников: матер. междунар. конф. Павлодар: ПГУ им. С. Торайгырова, 2004. 28-31-бб.

5. Кызласов Л.Р. А.Х. Маргулан. К портрету ученого и человека // Ғұлама. Тағдыр. Тағылым (Әлкей Марғұлан туралы естелік мақалалар, деркті әңгімелер, очерктер, өлең арнаулар). Павлодар, 2004. 19-26-бб. 
6. Құрманқұлов Ж., Байгунаков Д. Қазақстанның қола дәуірі (зерттелу тарихы мен негізгі мәселелері). Алматы: «Кие», 2008. 192 б.

7. Маргулан А.X. Археологические разведки в Центральном Казахстане (1946 г.) // Известия АН КазССР. Сер. историч. 1948. Вып. 4. С. 119-144.

8. Маргулан А.Х. Древние караванные пути через пустыню Бетпак-дала // Вестник АН КазССР. 1949. № 1 (46). С. 68-79.

9. Маргулан А.Х. Из истории городов строительного искусства древнего Казахстана. Алматы: изд-во АН КазССР, 1950а. 125 с.

10. Маргулан А.Х. Историко-топографический фон восточной Бетпак-Далы // ВАН КазССР. 1950б. № 6. С. 61-72.

11. Маргулан A.X. Раскопки погребения воина XIV века в долине р. Нуры // ТИИАЭ АН КазССР. 1959. Т. 7. С. 248-261.

12. Маргулан A.X. Открытие новых памятников культуры эпохи бронзы Центрального Казахстана // XXV Международный конгресс востоковедов: доклады делегации СССР. М., 1960. С. 10-11.

13. Маргулан А.Х. Бегазы-Дандыбаевская культура Центрального Казахстана. Алма-Ата: Наука, 1979. 360 с.

14. Маргулан А.Х., Акишев К.А., Кадырбаев М.К., Оразбаев А.М. Древняя культура Центрального Казахстана. Алма-Ата: Наука, 1966. 435 с.

15. Марвұлан Ә.Х. Ежелгі жыр аңыздар. Алматы: «Жазушы», 1985. 368 б.

16. Маргулан Д.А. Методологические проблемы исторической науки и научное творчество А.Х. Маргулана // Методы научного познания. Алматы, 1996. С. 108-121.

\section{Автор туралы мәліметтер:}

Манапова Әлия Мерекеқызы - тарих ғылымдарының кандидаты, директорының орынбасары, Ә.Х. Марғұлан атындағы Археология институты (Алматы, Қазақстан); merekeevna@mail.ru

\section{НАСЛЕДИЕ АЛЬКЕЯ ХАКАНОВИЧА МАРГУЛАНА}

\section{А.М. Манапова}

Имя Алькея Хакановича Маргулана широко известно в мировой науке. Наследие, оставленное нам А.X. Маргуланом - это бесценный вклад в сокровищницу мировой культуры. А.Х. Маргулан был организатором и руководителем ЦентральноКазахстанской археологической экспедиции АН КазССР, которая первой покрыла своими маршрутами Сарыарку. Выход в свет таких монографий, как «Из истории городов и строительного искусства древнего Казахстана», «Бегазы-дандыбаевская культура Центрального Казахстана», явилось крупным событием в научной жизни страны. Всего перу исследователя принадлежит более 300 научных и научнопопулярных публикаций, посвященных важнейшим проблемам археологии, архитектуры, этнографии, древней и средневековой истории, истории культуры и литературы Казахстана. Академик Алькей Хаканович Маргулан - разносторонний ученый. В каждый предмет своего изучения он вносил весомый вклад. Особенно важным является изучение археологического культурного наследия, оставленное А.Х. Маргуланом.

Ключевые слова: археология, А.Х. Маргулан, Центральный Казахстан, наследие, архитектура, этнография, каменный век, бронзовый век, металлургия, средневековье, города

\section{HERITAGE OF ALKEY MARGULAN}

\section{A.M. Manapova}

The name of Alkey Margulan is widely known in the world science. The heritage, left to us by A.Kh. Margulan, is invaluable contribution to the treasury of the world culture. A.Kh. Margulan was organizer and head of Central Kazakhstan archaeological expedition of the Academy of Sciences of KazSSR, the first which covered Saryarka with its routes. Publication of such monographs as "From the history of cities and civil engineering of the ancient Kazakhstan", "Begazy-Dandybay culture of Central Kazakhstan", was large event in the scientific life of the country. In total more than 300 scientific and popular scientific publications devoted to the major problems of archaeology, architecture, ethnography, 
ancient and medieval history, history of culture and literature of Kazakhstan belong to the pen of the researcher. Academician Alkey Margulan is versatile scientist. He brought powerful contribution in each subject of the research. His contribution to studying the archaeological cultural heritage is especially important.

Keywords: archaeology, A.Kh. Margulan, Central Kazakhstan, heritage, architecture, ethnography, Stone age, Bronze age, metallurgy, Middle ages, cities

\section{REFERENCES}

1. Baipakov, K. M., Akishev, K. A. 1994. In Qazaq tarihy, 2, 7-10 [in Qazaq].

2. Bibliografiya Uchenyh Kazahstana. A.Kh. Margulan (Bibliography of Scientists of Kazakhstan. A.Kh. Margulan). 1984. Alma-Ata: "Nauka" Publ. [in Russian].

3. Eleuov, M. E. 1999. Shu Talas onirlerinin ortagasyrlyq qalalary men mekenderi (VI-XIII g. basy): tarih gyl. dokt.... avtoref (The medieval towns and settlements of Shu and Talas (VI-XIII century begining): thez. of the Doctor of History). Almaty [in Qazaq].

4. Kumekov, B. E. 2004. In Istoriya civilizacii i duhovnoj kul'tury kochevnikov (The history of civilization and spiritual culture of nomads). Pavlodar: Pavlodar State University named S. Toraygyrov Publ., 28-31 [in Russian].

5. Kyzlasov, L. R. 2004. In Gulama. Tulga, Tagdyr. Tagylym (Alkey Margulan turaly estelik maqalalar, derkti angimeler, ocherkter, olen arnaular) (Memories, documentary stories, essays, poems about Alkey Margulan). Pavlodar, 19-26 [in Russian].

6. Kurmankulov, J., Baygunakov, D. 2008. Qazaqstannyn qola dauiri (zerttelu tarihy men negizgi maseleleri) (Kazakhstan in Bronze Ages (History of Studying and Basic Problems)). Almaty: «Kie» Publ. [in Qazaq].

8. Margulan, A. Kh. 1948. In Izvestiya AN KazSSR. Ser. istorich. (News of the Kazakh SSR. Ser. History), 4, 119-144 [in Russian].

9. Margulan, A. Kh. 1950a. Iz istorii gorodov stroitel'nogo iskusstva drevnego Kazahstana (From the history of the cities of construction art of ancient Kazakhstan). Almaty: Academy of Sciences of the Kazakh SSR Publ. [in Russian].

10. Margulan, A. Kh. 1950b. In Vestnik AN KazSSR (Bulletin of the Kazakh Academy of Sciences), 6, 61-72 [in Russian].

11. Margulan, A. Kh. 1960. In 25-yi Mezhdunarodnyj kongress vostokovedov: doklady delegacii SSSR (25th International Congress of Orientalists: reports of the delegation of the USSR). Moscow, 10-11 [in Russian].

12. Margulan, A. Kh. 1979. Begazy-Dandybaevskaya kul'tura Central'nogo Kazahstana (Begazy-Dandybay culture of Central Kazakhstan). Alma-Ata: "Nauka" Publ. [in Russian].

13. Margulan, A. Kh., Akishev, K. A., Kadyrbayev, M. K., Orazbayev, A. M. 1966. Drevnyaya kul'tura Central'nogo Kazahstana (The ancient culture of Central Kazakhstan). Alma-Ata: "Nauka" Publ. [in Russian].

14. Margulan A.Kh. 1985. Ejelgi zhyr anyzdar (The ancient jyr anyzdar). Almaty: "Jazushy" [in Russian].

15. Margulan, D. A. 1996. In Metody nauchnogo poznaniya (Methods of scientific knowledge). Almaty, 108-121 [in Russian].

\section{About the Author:}

ManapovaAliya M. Candidate ofHistorical Sciences, Deputy Director, A.Kh. Margulan Archeology Institute, Almaty, Kazakhstan; merekeevna@mail.ru

\footnotetext{
Мүдделер қақтығысы туралы ақпаратты ашу. Автор мүдделер қақтығысының жоқтығын мәлімдейді. / Раскрытие информации о конфликте интересов. Автор заявляет об отсутствии конфликта интересов. / Disclosure of conflict of interest information. The author claims no conflict of interest.

Мақала туралы ақпарат / Информация о статье / Information about the article.

Редакцияға түсті / Поступила в редакцию / Entered the editorial office: 15.10.2018.

Рецензенттер мақұлдаған / Одобрено рецензентами / Approved by reviewers: 22.10.2018.

Жариялауға қабылданды / Принята к публикации / Accepted for publication: 27.10.2018.
} 